\title{
HANTINGTONO LIGOS KLINIKINIAI SIMPTOMAI
}

\author{
Kastytis Budrevičius \\ Vilniaus universitetas, Medicinos fakultetas
}

Raktažodžiai: Hantingtono liga, genetika, klinikiniai simptomai, CAG, chorèja.

\section{Santrauka \\ Tyrimo tikslas - išanalizuoti ir aptarti įrodymais pa- grịstą informaciją apie Hantingtono ligos klinikinius simptomus. Atlikta sisteminè mokslinès literatūros bei dokumentų apžvalga ir analizè. Rezultatai parodé, kad Hantingtono liga yra paveldimas, progresuojantis neuro- degeneracinis sutrikimas, kuriam būdingi choreiforminiai judesiai, psichinès problemos ir demencija. Klinikiniai Hantingtono ligos simptomai skirstomi ị motorinius, ko- gnityvinius ir psichiatrinius. Dažniausias tipinis motori- nis simptomas yra choreja - nekontroliuojami judesiai, galintys atsirasti bet kurioje kūno dalyje. Kognityviniai simptomai pasireiškia demencija, sutrikusia kalba, nege- bẻjimu atlikti keletą užduočių vienu metu. Dažniausi psi- chiatriniai simptomai yra depresija, irzlumas, psichozé, apatija ir hiperseksualinis elgesys.}

\section{Ivadas}

Hantingtono liga yra paveldimas, progresuojantis neurodegeneracinis sutrikimas, kuriam būdingi choreiforminiai judesiai, psichinès problemos ir demencija. Šią ligą sukelia citozino-adenino-guanino (CAG) trinukleotido pasikartojimų išsiplètimas Hantingtono (HTT) gene, kuris randamas 4 p16.3 chromosomoje, koduojančioje Hantingtono baltymą [1]. Ši liga paveldima autosominiu dominantiniu būdu. Pradinis ligos sunkumas bei pasireiškimo amžius priklauso nuo CAG trinukleotido pasikartojimų skaičiaus. Sveikų asmenų organizme gali pasitaikyti CAG pasikartojimų, kurie varijuoja nuo 6 iki 26 kartų. Tarpinis alelių kopijų skaičius yra laikomas pasikartojimas nuo 27 iki 35 ir toks kopijų skaičius retai sukelia ligą [2]. Esant daugiau nei 27 pasikartojimams, aleliai yra nestabilūs ir turi tendenciją plèstis ateinančiose kartose, tai reiškia, jog tokių pacientų palikuonys turès didesnị kopijų skaičių ir liga pasireikš anksčiau. Nustatyta Hantingtono ligos išsivystymo riba yra 36 pakartojimai, tačiau ligos fenotipo ekspresija gali būti skirtinga esant 36-39 CAG pasikartojimams [2].
Tyrimo tikslas - išanalizuoti ir aptarti ịrodymais pagrịstą informaciją apie Hantingtono sindromo klinikinius simptomus.

\section{Tyrimo medžiaga ir metodai}

Taikyta sisteminè mokslinès literatūros bei dokumentų apžvalga ir analizè. Duomenų buvo ieškoma Google Scholar, UpToDate, Cochrane bei Medline (PubMed) duomenų bazèse. Visateksčiai straipsniai atrinkti, jei jų pavadinimas, santrauka ar reikšminiai žodžiai nurodè, kad tyrimas tinkamas įtraukti i šią apžvalgą. Pasirinktos tik anglų kalba skelbtos publikacijos. Naudoti raktažodžiai: Huntington's disease, genetics, clinical features, CAG, chorea.

\section{Tyrimo rezultatai}

Ligos pirmieji simptomai dažniausiai pasireiškia apie 40-50 gyvenimo metus, nors liga paveldima, o defektyvus baltymas kaupiasi nuo gimimo [2]. Pagrindiniai simptomai skirstomi ic tris grupes: motoriniai, psichiatriniai ir kognityviniai [3]. Motoriniai simptomai dažniausiai pasireiškia chorèja. Chorèja - tai nenormalūs, nekontroliuojami, nestereotipiniai judesiai, kurie gali atsirasti visose kūno dalyse. Ligos pradžioje šie judesiai būna smulkūs ir gali būti painiojami su neramumu, tačiau dažnai pacientai nežino ir nepastebi naujų pokyčių. Hantingtono liga pasireiškia ir hipotonija bei hiperrefleksija. Manoma, jog tai vieni iš ankstyvujų simptomų. Ligos eigoje atsiranda distonija, matoma ranku judesiuose, pacientui einant. Progresuojant ligai, simptomai ryškejja, pradeda trukdyti kasdienei veiklai, kol galiausiai žmogus praranda galimybę kontroliuoti judesius. Dar viena motorikos simptomų subgrupé - akių simptomai [4]. Darosi sunku kontroliuoti žvilgsnio kryptị, kuris vis nukrypsta nenorima linkme, todèl ligonis turi žvilgsnị koreguoti - stebimos koreguojamosios sakados [5]. Kognityvinių simptomų grupé pasireiškia demencija, sunkumu vykdyti sprendimus ir atlikti keletą užduočių vienu metu. Atlikdami tokių pacientų ištyrimą, galime pastebèti sutrikusią kalbą, jie prasčiau atliks protinès būklès tyrimo testus [6]. Psichiatriniai simptomai dažniausiai pasireiškia depresija. Depresijos pasireiškimas sergantiesiems Hantingtono liga varijuoja nuo 
9 iki 63 proc., dažnai tai yra vienas iš anksčiausiai stebimu ligos simptomų. Manoma, jog depresija gali išsivystyti dèl aktyvių smegenų degeneracinių procesų, tiksliau - ankstyvojo neuronų praradimo uodeguotajame branduolyje, kuris turi tiesiogini ryšį su limbine sistema, atsakinga už žmogaus emocijas. Depresija tiek vyrams, tiek moterims pasireiškia vienodu dažniu, o tai skiriasi nuo sveikujų populiacijos, todèl manoma, jog depresija gali vystytis kaip atsakas ị šios ligos diagnozę [7]. Psichiatriniai simptomai dar gali pasireikšti irzlumu. Irzlumas apima kantrybès, tolerancijos praradimą, sunkiai valdomą pyktị. Tai lemia ne tik susierzinimas dèl ligos fakto, tačiau ir dryžuotojo kūno bei orbitofrontaliniųsubkortikalinių ryšių degeneracijos. Tai lemia ir socialiai nepriimtino elgesio atsiradimą vèlesnèse stadijose. Trečioji psichiatrinių simptomų grupe yra psichozè. Ji pasireiškia paranoja, šizofreniją primenančiais kliedesiais (3-11\% pacientų), tačiau palyginus su depresijos simptomatika, pasitaiko reikšmingai rečiau. Ketvirtasis aprašomas psichiatrinis sindromas yra apatija. Apatija apibūdinama kaip motyvacijos sutrikimas, kai prarandamas arba sumažeja tikslo siekiantis elgesys ir pažintinè veikla. Šis sindromas pasireiškia nuo 52 iki 76 proc. pacientų, gali būti depresijos dalimi ir vis labiau stipreti, progresuojant ligai. Apatijos atsiradimas bandomas aiškinti juostinio vingio ir požievio jungties pažaida. Taip pat pastebimas obsesyvus elgesys, kuris pasireiškia nuo $7 \mathrm{iki}$ 50 proc. pacientu, nerimo sutrikimai, disinhibicija, impulsyvumas bei hiperseksualinis elgesys, dažnesnis vyrams [8].

\section{Išvados}

1. Hantingtono ligos klinikiniai simptomai skirstomi i motorinius, kognityvinius ir psichiatrinius.

2. Dažniausias motorinis simptomas yra chorèja, tačiau stebimi ir kiti: hipotonija, hiperrefleksija, distonija.

3. Kognityviniai simptomai dažniausiai pasireiškia demencija, sutrikusia kalba, sutrikusiu gebejjimu atlikti keletą užduočių vienu metu.

4. Depresija yra dažniausia psichiatrinių simptomų išraiška, taip pat stebimas irzlumas, psichozè, apatija, hiperseksualinis elgesys.

\section{Literatūra}

1. A novel gene containing a trinucleotide repeat that is expanded and unstable on Huntington's disease chromosomes. The Huntington's Disease Collaborative Research Group. Cell 1993;72(6):971-83.

https://doi.org/10.1016/0092-8674(93)90585-E

2. Walker FO. Huntington's disease. Lancet Lond Engl 2007;369(9557):218-28.

https://doi.org/10.1016/S0140-6736(07)60111-1
3. Roos RA. Huntington's disease: a clinical review. Orphanet J Rare Dis 2010;5:40.

https://doi.org/10.1186/1750-1172-5-40

4. Ross CA, Tabrizi SJ. Huntington's disease: from molecular pathogenesis to clinical treatment. Lancet Neurol 2011;10(1):83-98. https://doi.org/10.1016/S1474-4422(10)70245-3

5. Ha AD, Jankovic J. Exploring the correlates of intermediate CAG repeats in Huntington disease. Postgrad Med 2011;123(5):11621.

https://doi.org/10.3810/pgm.2011.09.2466

6. Maat-Kievit A, Losekoot M, Zwinderman K, Vlis MV-VD, Belfroid R, Lopez F, et al. Predictability of Age at Onset in Huntington Disease in the Dutch Population. Medicine (Baltimore). 2002;81(4):251-9. https://doi.org/10.1097/00005792-200207000-00001

7. Hubers A a. M, Reedeker N, Giltay EJ, Roos R a. C, van Duijn E, van der Mast RC. Suicidality in Huntington's disease. J Affect Disord 2012;136(3):550-7.

https://doi.org/10.1016/j.jad.2011.10.031

8. Wetzel HH, Gehl CR, Dellefave-Castillo L, Schiffman JF, Shannon KM, Paulsen JS, et al. Suicidal ideation in Huntington disease: the role of comorbidity. Psychiatry Res 2011;188(3):372-6. https://doi.org/10.1016/j.psychres.2011.05.006

\section{CLINICAL FEATURES OF HUNTINGTON'S DISEASE K. Budrevičius}

Keywords: Huntington's disease, genetics, clinical features, CAG, chorea.

Summary

Huntington's disease is a hereditary, progressive neurodegenerative disorder characterised by choreiform movements, cognitive problems and dementia. Clinical features of Huntington's disease include motor, cognitive and psychiatric symptoms. Chorea - irregular, unpredictable muscle movements in any part of the body is the most common motor symptom. Cognitive impairments in Huntington's disease include dementia, speech disorders and decreased multitasking ability. The most common psychiatric disorders in Huntington's disease are depression, heightened irritability, psychosis, apathy and hypersexual behaviour.

Conclusions. 1. Clinical features of Huntington's disease include motor, cognitive and psychiatric symptoms. 2. Chorea is the most frequently encountered motor symptom, though hypotonia, hyperreflexia and dystonia also occur. 3. Cognitive impairments include dementia, speech disoders and decreased multitasking ability. 4. Depression is the most common psychiatric disorder, however, heightened irritability, psychosis, apathy and hypersexual behaviour are also associated with Huntington's disease.

Correspondence to: kastytis.budrevicius@yahoo.com

Gauta 2021-08-18 